\title{
Remarks on Behavior of Horse Guard Wasps (Hymenoptera, Crabronidae, Bembicinae) and Interrupted Hematophagism of Horse Flies (Diptera, Tabanidae)
}

\author{
Ronald Rodrigues Guimaraes ${ }^{1}$, Ronald Rodrigues Guimarães Junior ${ }^{2}$, Sandor Buys ${ }^{3}$, Harlan Ronald Rodrigues \\ Storti ${ }^{4}$, Roney Rodrigues Guimarães ${ }^{5}$, Eduardo Dias Wermelinger ${ }^{1} \&$ Raimundo Wilson Carvalho ${ }^{1}$ \\ ${ }^{1}$ Escola Nacional de Saude Pública Sérgio Arouca, Centro de Educação e Pesquisas em Medicina Ambiental, \\ Brazil \\ ${ }^{2}$ Estudante de graduação em Análise de Sistemas, na Associação Brasileira de Ensino Universitário, Nova Iguaçu, \\ RJ., Brazil \\ ${ }^{3}$ Coleção Entomológica do Instituto Oswaldo Cruz, Brazil \\ ${ }^{4}$ Graduado em Letras-Inglês pela Universidade Iguaçu, professor de inglês na "Cultura Inglesa" e "Curso \\ Tamandaré”. Proficiência em inglês no nível Toefl, Brazil \\ ${ }^{5}$ Universidade Estácio de Sá, Centro Universitário de Barra Mansa, Brazil \\ Correspondence: Ronald Rodrigues Guimaraes, Escola Nacional de Saude Pública Sérgio Arouca, Centro de \\ Educação e Pesquisas em Medicina Ambiental, Brazil. E-mail: cemabiosaude@gmail.com
}

$\begin{array}{lc}\text { Received: May 11, } 2015 & \text { Accepted: May 24, } 2015 \quad \text { Online Published: October 28, } 2015 \\ \text { doi:10.5539/ijb.v8n1p27 } & \text { URL: http://dx.doi.org/10.5539/ijb.v8n1p27 }\end{array}$

\begin{abstract}
During studies on tabanid fauna on Marambaia Island, Mangaratiba, Brazil, the authors captured 71specimens of two species of solitaire sand wasps hunting horseflies, Stictia punctata (Fabricius, 1775) and Stictia signata signata (Linnaeus, 1758). Wasps interact with horseflies demonstrating outstanding behavior, interrupting the hematophagism, which enhances tabanids ability to transmit pathogenic agents to natural hosts.
\end{abstract}

Keywords: ethological factor, mechanical transmission, tabanids, sand wasps, vector epidemiology

\section{Introduction}

Horseflies are important transmitters of several pathogens for animals and occasionally to humans (Turcatel, Carvalho \& Rafael, 2007). Usually, they are they are involved in mechanical transmission of various agents, such as virus of equine infectious anemia, agents of bovine and equine trypanosomiasis, anaplasmosis, borreliosis, anthrax and human tularemia (Herrera et al., 2011). They can also act as biological vectors and if so, can transmit the nematode Loa loa, that causes human loiasis in Africa and Elaeophora schineideri and Dirofilaria remeri to kangaroo (Krinsky, 1976). They still meet all the ethological and structural characteristics necessary to be a good mechanical vector: make interruption of hematophagism, have high mobility and large mouthparts that can carry and transfer the etiologic agent (Foil, 1989; Marcondes, 2009). Until now, the explanation of interrupted hematophagism is the fact that their sting is very painful. The mouth parts are short, wide and strong, and has shaped jaws with sharp blades and laciniae with teeth at the end, which pierce the skin of the host, with scissor movement and cause severe pain. Pain makes its victims ward them off before they complete hematophagism, forcing tabanids to seek another host or return to it after a while. The labellum lobes are large and provided with sclerotized channels serving to distribute the saliva, but can store and keep blood collection in which the pathogens are present (Krenn \& Aspöck, 2012); and they are considered powerful flying flies. Finally, there is another important factor, not commonly referred to, which makes them good mechanical vectors: the persistence that tabanids have to attack their victims, and that is why some species are also called 'bull-dog flies' (Thomas \& Marshall, 2009). Other factors are also related to mechanical transmission capacity by tabanids, as the density of their population, proximity to susceptible hosts, time spent in the period between heteroxenic hematophagisms, high infectivity and/or high levels of the agent in the blood stream of the host and the strength of the etiological agent (Barros \& Foil, 2007). 
On the other hand, tabanids suffer intense predation from several species of insects, such as robber flies of family Asilidae (Latreille, 1802) (Diptera) and various hunting solitary wasps of subfamily Bembicinae (Latreille, 1802) (Hymenoptera: Crabronidae). Some of these wasps have an impact on the population of tabanids, especially because they have remarkable predilection for predating them (Philippi \& Eberhard, 1986; Kurczewsk, 2003). The fact of this wasps' preference for hunting horse flies explains the evolution of specialized trophic behavior of the wasps in relation to tabanids (Evans, 2002).

During studies on the ecology of tabanids in Marambaia Island, several specimens of two species of wasps were caught hunting the tabanids around horses on pasture. Thus, the present paper reports the occurrence of two species of "horse guards" and discusses some aspects of the epidemiology of interrupted hematophagism to enhance mechanical transmission of pathogens.

\section{Material and Methods}

\subsection{Area of Study}

Marambaia Island is a strip of land $42 \mathrm{~km}$ long, with an area of approximately $81 \mathrm{~km}^{2}$, located on Costa Verde, south of the State of Rio de Janeiro, in the city of Mangaratiba, in Sepetiba Bay entry, between $23^{\circ} 00$ and $23^{\circ} 06^{\prime} \mathrm{S}$ and $43^{\circ} 45^{\prime}$ and $44^{\circ} 01^{\prime} \mathrm{W}$ (Figure 1a). Actually, it's not an island, as it connects to the mainland by a narrow sandy strip characteristic of sandbanks; it is called an island due to the size of the elevations that rise at the west end, reaching 647 meters high. It has an area of environmental preservation with tropical primary forests mountain and spits.

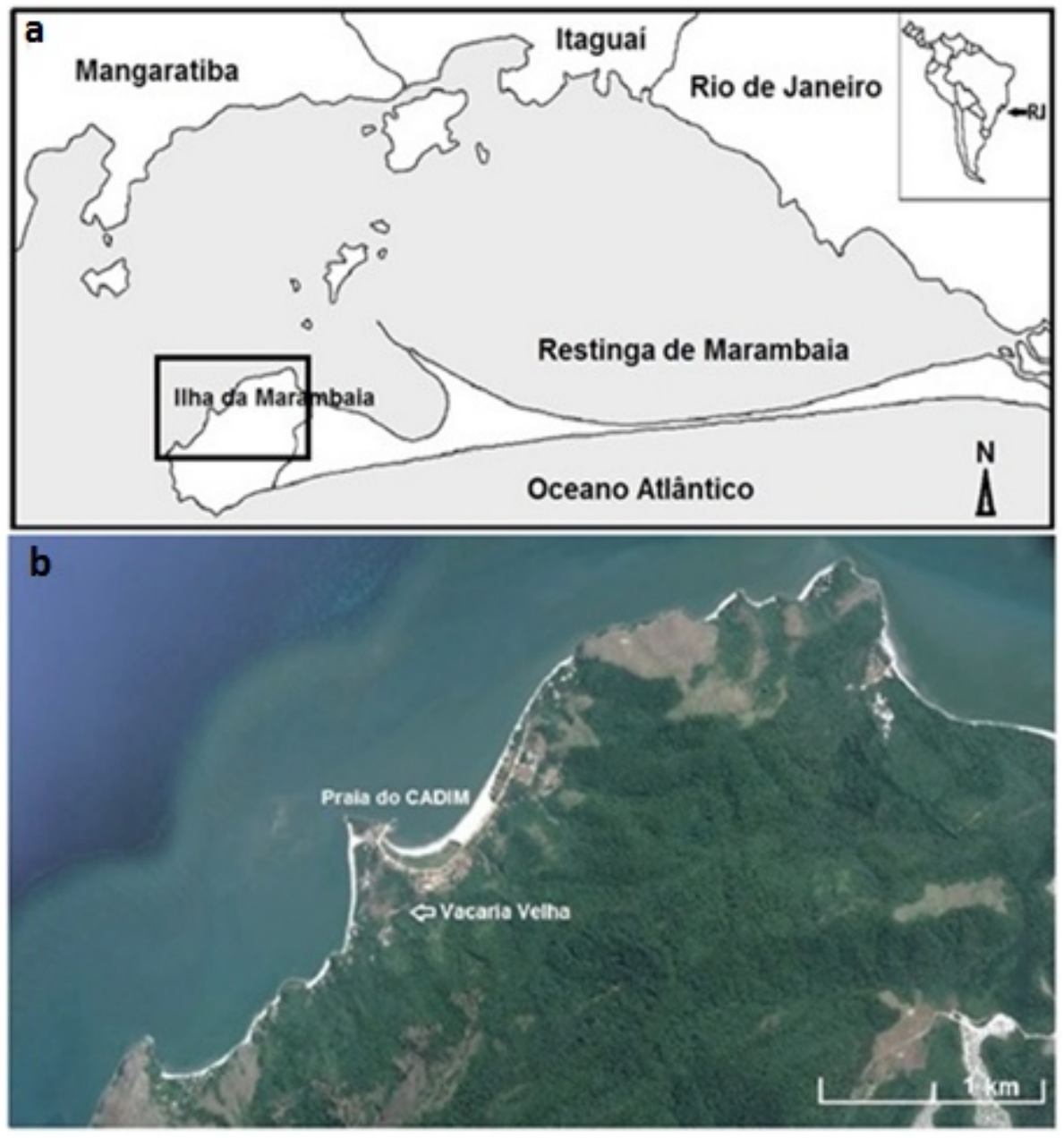

Figure 1. Geographic location (1a) and site of collection (1b) of horse guard wasps on Marambaia Island, Mangaratiba, Rio de Janeiro state, Brazil.

Sources: Figure 1a. Souza et al., 2007. Figure 1b. GoogleMaps. Retrieved from www.google.com.br/maps/@23.03 $16476,43.9261133,19073 \mathrm{~m} / \mathrm{data}=! 3 \mathrm{ml} ! 1 \mathrm{e} 3$ ?hl=pt-BR 


\subsection{Samples Specimens}

During October and December 2013, a study was performed to know the tabanids ecology on Marambaia Island, and horse guard wasps were captured preying on tabanids (Guimarães et al., 2014. The study area is characterized by an ecotone between Atlantic forest and meadow, near a pond, known as 'Vacaria Velha' $\left[23^{\circ} 03^{\prime} 47^{\prime \prime} \mathrm{S}\right.$ and $\left.43^{\circ} 59^{\prime} 16^{\prime \prime} \mathrm{W}\right]$ (Figure 1b). The collections were made around a horse in their pasture environment, which has enhanced the yield of the catch. Wasps and tabanids were captured by manual insect hand net. Wasps and tabanids were killed in mortal chamber with ethyl acetate and pinned.

\subsection{Identification of Collected Specimens}

The wasps were identified according Parker (1929), Willink (1947) and Bohart and Menke (1976); and tabanids according Kröber (1930), Fairchild (1972, 1983) and Coscarón and Papavero (2009). The specimens are deposited in the Entomological Collection of the Instituto Oswaldo Cruz-CEIOC, and in Center for Education and Research in Environmental Medicine-CEMA. Collection and transport of biological samples were authorized by Brazilian Chico Mendes Institute for Biodiversity, Ministry of Environment, license 33382-1, SISBIO-IBAMA.

\section{Results}

During the study period, 71 specimens of wasps were captured in 'Vacaria Velha': 49 specimens (61.0\%) of Stictia punctata (Fabricius, 1775) and 22 (31.0\%) of Stictia signata signata (Linnaeus, 1758) (Figures $2 \mathrm{a}$ and b). These species are known to have the habit of hunting tabanids around horses and so are called "horse guards" or "police insect" (Philippi \& Eberhart, 1986). They are solitary wasps that build nest in sandy soil, where they deposit their eggs. The larvae are fed with insects hunted by adult females (Genaro, 1999). They behave differently with respect to the time that they spend on hunting around the animal: S. punctata, a predominantly black and more robust wasp, measuring about $2.5 \mathrm{~cm}$, remains around the horse for 5 to 10 seconds chasing tabanids, after which, they fly away; they take even less time if animal is in a sunny place. The other species, $S$. signata predominantly greenish yellow and black, is slightly smaller, measuring about 2 inches remains hunting around the horse for 15 to 25 seconds, despite the sunny environment. The two species of wasps flying through the legs, chest, neck, belly, abdomen and hips; when the animal is grazing they also fly around the head.
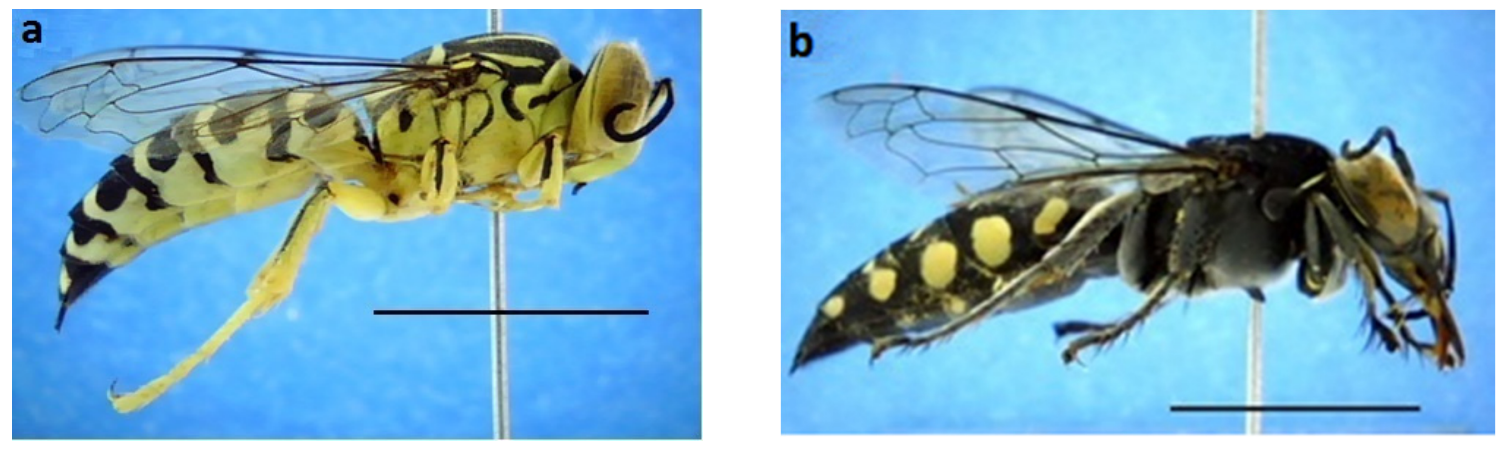

Figure 2. Habitus of Stictia punctata (Fabricius, 1775) (a) and Stictia signata signata (Linnaeus, 1758) (b), species of horse guard wasps, collected on Marambaia Island. Author photographs. The horizontal black bar represents $1 \mathrm{~cm}$

\section{Discussion}

Both wasps' species were captured preying on tabanids species Diachlorus bivittatus Wiedemann, 1828, Tabanus occidentalis Linnaeus, 1758 and Phaeotabanus litigiosus Walker, 1850. However, the most important fact observed is that tabanids perceive and react to the presence of wasps. It is known that usually blood-sucking insects are stimulated by hunger, seeking the host, initially by random movements or sometimes led by a stereotypical pattern of research, more or less confined to their habitat (Dethier, 1957). However from the moment in which the parasite is on its host, it is entirely controlled by their stimuli and may sometimes dispose the environment. Being still close to the animal used as bait, some tabanids, do realize the presence of wasps, they can get away, avoiding the attack, and do not return while the wasps are close. This perception is probably due to the warning given by the buzz of wings of wasps in flight.

When four or five wasps are flying around the horse, there are no tabanids trying to feed themselves, but when the wasps fly away, or as observed in this study, when the wasps were captured by an insect hand net, the tabanids 
return to feed. Thus, the nickname of "horse guards" takes on a different dimension so far accepted. Wasps not only protect horses catching horse flies that are approaching them, but also repel them preventing to approach the animal. Sometimes when tabanids approach and reduce the flight speed, they are caught in flight; other times, the flies are captured after being landed, before or shortly after starting hematophagism.

In turn, tabanids can escape from the wasps's attacks when they realize their approach, rapidly changing the direction of the flight. When tabanids land and realize the impending attack, they can also immediately take flight. Likewise, when they start hematophagism, they can also escape by lifting flight before the fatal wasp approach, and this is a rare situation than before. The fact that tabanids manage to escape even after the start of hematophagism, is a behavioral interaction that is of great epidemiological importance because it determines the interrupted hematophagism. This agent transmission mechanism, as seen, is an important factor related to the ability of tabanids in making mechanical vectoring of trypanosomiasis and viruses (Clabough et al., 1991; Evans, 2002; Herrera et al., 2011).

The fact that not always the onslaught of hunting wasps is successful, i. e., the tabanids manage to escape, even after initiation of hematophagism, is closely related to the mechanical transmission capacity of pathogens. So, when it comes to explaining the interrupted hematophagism of tabanids, the reason pointed out was the pain caused by their bites (Marcondes, 2009), which causes reactions in the host trying to pull them apart as muscle tremors, tail movement, hit with the head and kick (Davies, 1990). But there is another factor related to mechanical transmission of etiologic agents, hitherto not registered: the ability of tabanids to escape from the hunting wasps' attacks. High rates of interrupted hematophagism reduces the successful feeding of tabanids, increasing the number of blood feedings necessary to complete egg development, which also increases the possibility of mechanical transmission of pathogens. Certainly many attempts to complete the blood meal reduces energy intake from tabanids females, reducing their flight capacity and increase the risk of being killed, either by the host defenses, or predated by robber flies or horse guard wasps (Davies, 1990).

Natural enemies of pests has been used in biological control programs. However, in this case, in natural environment, paradoxically, a predator can influence a behavioral factor potentiating the transmission capacity of pathogens by vectors. To be sure, the more tabanids evade, interrupting hematophagism, the greater the chances of transmission, because although the wasps have shocked the population of tabanids, there will always be those who escape their attacks.

\section{References}

Barros, A. T. M., \& Foil, L. D. (2007). The influence of distance on movement of tabanids (Diptera: Tabanidae) between horses. Veterinary Parasitology, 144, 380-384. http://dx.doi.org/10.1016/j.vetpar.2006.09.041

Bohart, R. M., \& Menke, A. S. (1976). Sphecid wasps of the world - a generic revision. Oakland, CA: University of California Press. Retrieved from https:/ia802608.us.archive.org/19/items/bub_gb_FExMjuRhjpIC/ bub_gb_FExMjuRhjpIC.pdf

Clabough, D. L., Gebhard, D., Flaherty, M. T., Whetter, L. E., Perry, S. T., Coggins, L., \& Fuller, F. J. (1991). Immune-mediated thrombocytopenia in horses infected with equine infectious anemia virus. Journal of Virology, 65, 6242-6251. Retrieved from http://www.ncbi.nlm.nih.gov/pmc/articles/PMC250322/pdf/jvirol 00054-0600.pdf

Coscarón, S., \& Papavero, N. (2009). Catalogue of Neotropical Diptera: Tabanidae. Neotropical Diptera, 16, 1199. Retrieved from http://revistas.ffclrp.usp.br/ Neotropical_Diptera/article/viewFile/210/165

Davies, C. R. (1990). Interrupted Feeding of Blood-sucking Insects: Causes and Effects. Parasitology Today, 6(1), 19-22. http://dx.doi.org/10.1016/0169-4758(90)90387-J

Dethier, V. G. (1957). The sensory physiology of blood-sucking arthropods. Experimental Parasitology, 6, 68122. http://dx.doi.org/10.1016/0014-4894(57)90009-7

Evans. H. E. (2002). A review of prey choice in Bembicinae sand wasps (Hymenoptera: Sphecidae). Neotropical Entomology, 31, 1-11. http://dx.doi.org/10.1590/S1519-566X2002000100001

Fairchild, G. B. (1972). Notes on Neotropical Tabanidae (Diptera). XIII. The Genus Diachlorus O. S. The Florida Entomologist, 55(4), 219-229. http://dx.doi.org/10.2307/3493370

Fairchild, G. B. (1983). Notes on Neotropical Tabanidae (Diptera) XIX. The Tabanus lineola complex. Miscellaneous Publications of the Entomological Society of America, 57, 1-51.

Foil, L. D. (1989). Tabanids as Vector of Disease Agents. Parasitology Today, 5, 88-96. http://dx.doi.org/10.1016/ 0169-4758(89)90009-4 
Genaro, J. A. (1999). Parasitismo entre especies (Diptera, Hymenoptera) en los nidos de Stictia signata (Hymenoptera: Sphecidae). Revista de Biologia Tropical, 47, 535-538. http://dx.doi.org/10.1016/01694758(89)90009-4

Guimarães, R. R., Buys, S. C., Vivallo, F., Guimarães-Junior, R. R., Harlan-Ronald, R. S., Rodrigues-Guimarães, R., ... Carvalho, R. W. (2014). Bembicine wasps (Crabronidae, Bembicinae) of Marambaia Island (Mangaratiba, RJ, Brazil): preliminary inventory of species and bionomic notes. Acta Biológica Paranaense, 43, 77-84. http://dx.doi.org/10.5380/abpr.v43i0.39434

Herrera. H. M., Rocha, F. L., Lisboa, C. V., Rademaker, V., Mourão, G. H., \& Jansen, A. M. (2011). Food web connections and the transmission cycles of Trypanosoma cruzi and Trypanosoma evansi (Kinetoplastida, Trypanosomatidae) in the Pantanal Region, Brazil. Transactions of the Royal Society of Tropical Medicine and Hygiene, 105, 380-387. http://dx.doi.org/10.1016/j.trstmh.2011.04.008

Krenn, H. W., \& Aspöck, H. (2012). Form, function and evolution of the mouthparts of blood-feeding Arthropoda. Arthropod Structure \& Development, 4, 101-118. http://dx.doi.org/10.1016/j.asd.2011.12.001

Krinsky, W. L. (1976). Animal disease agents transmitted by horse flies and deer flies (Diptera: Tabanidae). Journal of Medical Entomology, 13, 225-275. http://dx.doi.org/10.1093/jmedent/13.3.225

Kröber, O. (1930). Die Tabanidenuntergattung Phaeotabanus Lutz. Zoologischer Anzeiger, 86, 273- 300.

Kurczewsk, F. E. (2003). Comparative nesting behavior of Crabro monticola (Hymenoptera: Sphecidae). Notheastermn Naturalist, 10, 425-450. http://dx.doi.org/10.2307/3858660

Marcondes, C. B. (Ed.) (2009). Doenças transmitidas e causadas por artrópodes. Editora Atheneu: São Paulo, Brazil.

Parker, J. B. (1929). A generic revision of the fossorial wasps of the tribes Stizini and Bembicini, with notes and descriptions of new species. Proceedings of the United States Natural Museum, 75, 1-203. http://dx.doi.org/10.5479/si.00963801.75-2776.1

Philippi, T., \& Eberhard, W. G. (1986). Foraging behavior of Stictia signata (Hymenoptera: Sphecidae). Journal of the Kansas Entomological Society, 59, 604-608.

Souza, M. C., Morim, M. P., Conde, M. M. S., \& Menezes, L. F. T. (2007). Subtribo Myrciinae O. Berg (Myrtaceae) na Restinga da Marambaia, RJ, Brasil. Acta Botanica Brasilica, 21(1). 49-63. http://dx.doi.org/10.1590/ S0102-33062007000100006

Thomas, A. W., \& Marshall, S. A. (2009). Tabanidae of Canada, east of the Rocky Mountains: photographic key to the species of Chrysopsinae and Pangoniinae. Canadian Journal of Arthropod Identification, 8. http://dx.doi.org/10.3752/cjai.2009.08.

Turcatel, M., Carvalho, C. J. B., \& Rafael, J. A. (2007). Mutucas (Diptera: Tabanidae) do estado do Paraná, Brasil: chave de identificação pictórica para subfamílias, tribos e gêneros. Biota Neotropica, 7, 265-278. http://dx.doi.org/10.1590/S1676-06032007000200029

Willink, A. (1947). Las especies argentinas de "Bembicini" (Hym.: Sphecidae: Nyssoninae). Acta Zoolologica Lilloana, 4, 509-651.

\section{Copyrights}

Copyright for this article is retained by the author(s), with first publication rights granted to the journal.

This is an open-access article distributed under the terms and conditions of the Creative Commons Attribution license (http://creativecommons.org/licenses/by/3.0/). 